\title{
Peran Media Cetak dalam Narasi Moderasi Islam Indonesia
}

\author{
Dudung Abdul Rohman \\ Balai Diklat Keagamaan Bandung \\ email:dungrabmani@yahoo.com
}

\begin{abstract}
This study aims to analyze the mass media's role in minimizing cases of violence with religious nuances. The research also seeks to explore the efforts of the Republika Newspaper in persuading the public regarding the moderation of Indonesian Islam. This study uses a qualitative-descriptive method to describe the Republika newspaper print media's role in publishing the moderation narrative of Indonesian Islam in the 2017-2019 period. This study indicates that the printed media of Koran Republika are trying to minimize violence through moderate news. Koran Republika is also seen as representing practical Islamic preaching. The research implication is expected to realize peaceful journalism as a medium for the actualization of universal Islam.
\end{abstract}

Keywords: Islamic moderation; Islamic media; Republika

\section{ABSTRAK}

Penelitian bertujuan menganalisis peran media massa dalam meminimalisir kasus-kasus kekerasan bernuansa agama. Selain itu, penelitian berupaya untuk menggali upaya Koran Republika dalam mempersuasi khalayak mengenai moderasi Islam Indonesia. Penelitian ini menggunakan metode kualitatifdeskriptif untuk menggambarkan peran media cetak Koran Republika dalam mempublikasikan narasi moderasi Islam Indonesia pada periode 2017-2019. Hasil penelitian ini menunjukkan, bahwa media cetak Koran Republika berupaya meminimalisir kekerasan melalui berita-berita yang moderat. Koran Republika juga dipandang merepresentasi dakwah Islam moderat. Implikasi penelitian diharapkan memberikan sumbangsih dalam mewujudkan jurnalistik damai sebagai media aktualisasi Islam universal.

Kata Kunci: Moderasi Islam; Media Islam; Republika. 


\section{PENDAHULUAN}

Narasi moderasi Islam dimaksudkan untuk menghalau (melawan) opini dan stigma masyarakat Barat yang menganggap Islam identik dengan gerakan terorisme yang merugikan citra umat Islam dalam percaturan internasional pasca tragedi 11 September 2001. Sebagai reaksinya muncul sentimen agama yang menggunakan teks keagamaan seperti konsep jihad untuk memicu sentimen anti Barat dan untuk melegitimasi aksi teror yang bernuansa agama. Menurut Abdurrahman Mas'ud (2011), bahwa tafsir konsep jihad seperti ini jelas tidak sejalan dengan misi kedamaian dan kemanusiaan dalam ajaran Islam. Apalagi bila aksi kekerasan ini dilakukan di Indonesia yang masyarakat Muslimnya memiliki karakter moderat, santun, toleran, dan simpatik. Mereka sangat menghormati keragaman, identitas kebudayaan, dan kearifan lokal sebagai tradisi pribumi.

Menurut Hanafi (2018:19), bahwa munculnya pandangan stereotif (prasangka) yang kurang simpatik terhadap Islam dan umat Islam disebabkan oleh dua hal: pertama, ketidaktahuan Barat tentang Islam yang sebenarnya, karena basis pengetahuan mereka tentang Islam dibangun dari dokumen tulisan orientalis pada masa penjajahan dahulu yang mewariskan kebencian terhadap Islam; kedua, kerancuan sebahagian umat Islam sendiri dalam memahami konsep jihad dan perang dalam Islam dan mempersamakannya dengan terorisme dalam pandangan mereka.

Terjadinya tindakan kekerasan dan pengrusakan bernuansa agama bisa disebabkan oleh sentimen agama yang berlebihan dan pemahaman terhadap teks-teks keagamaan yang keliru. Atau dengan ungkapan lain, bisa jadi lantaran pemahaman agama yang cenderung ekstrem. Misalnya terdapat sekelompok Muslim yang hanya memiliki tafsir tunggal tentang kebenaran dari agama yang diyakininya, sehingga menutup pintu dialog dengan kelompok yang bersebrangan pemahaman. Padahal penafsiran terhadap suatu teks keagamaan sangat beragam, sehingga memunculkan madzhab-madzhab pemikiran baik dalam bidang kepercayaan yang memunculkan Ilmu Kalam maupun dalam ritual keagamaan yang memunculkan Ilmu Fiqih. Apalagi bila dikaitkan dengan dinamika zaman sekarang yang membuka kran kebebasan dan keterbukaan, maka yang namanya perbedaan pemahaman dan penafsiran terhadap teks keagamaan bisa terjadi setiap saat dan terbuka sangat lebar. Di sinilah pentingnya pemahaman agama yang terbuka dan komprehensif sehingga dapat menghargai perbedaan dan keragaman.

Konteks ini penting untuk menarasikan dan mewacanakan tentang moderasi Islam yang dapat memediasi dua kutub perbedaan pemahaman agama yang dipandang ekstrem tersebut. Karena moderasi Islam meniscayakan pemahaman keislaman yang seimbang antara pengamalan agama sendiri 
(eksklusif) dan penghormatan kepada praktik beragama orang lain yang berbeda keyakinan (inklusif). Menurut Lukman Hakim (dalam Kementerian Agama, 2019:20), bahwa keseimbangan atau jalan tengah dalam praktik beragama ini niscaya akan menghindarkan kita dari sikap ekstrem berlebihan, fanatik dan sikap revolusioner dalam beragama. Sehingga dapat disimpulkan, bahwa moderasi Islam bisa menjadi solusi atas hadirnya dua kutub ekstrem dalam beragama, kutub ultra-konservatif atau ekstrem kanan di satu sisi, dan liberal atau ekstrem kiri di sisi lain. Ia pun mengatakan, bahwa dalam masyarakat multikultural seperti Indonesia, moderasi beragama (Islam) bisa jadi bukan pilihan, melainkan keharusan.

Melalui konteks inilah urgensi dan signifikansi narasi dan publikasi moderasi Islam melalui media cetak. Tentu tidak semua media cetak dapat dengan terbuka menarasikan moderasi Islam karena ini berhubungan dengan paham dan gerakan keagamaan. Di antara media cetak yang representatif mempublikasikan narasi moderasi Islam adalah Harian Umum atau Koran Republika. Ini sejalan dengan profil Koran Republika yang memadukan ciri khas kebangsaan dan keislaman. Juga segmen pembacanya rata-rata komunitas Muslim perkotaan (kosmopolitan). Sebagaimana diungkapkan Kasman (2010:179), bahwa Koran Republika secara konsisten dan kontinyu menyiarkan berita dan opini tentang agama Islam. Karena dalam publikasi Koran Republika mempunyai beberapa misi, di antaranya misi agama, yaitu: (1) Menyiarkan Islam; (2) mempromosikan semangat toleransi; (3) Mewujudkan Islam rahmatan lil'alamin dalam segala bidang kehidupan; (4) Membela, melindungi, dan melayani kepentingan umat.

Pengkajian tentang moderasi Islam telah banyak dilakukan, terutama pasca tragedi 11 September 2011 yang menempatkan terorisme menjadi musuh bersama. Di antara asumsi terjadinya terorisme bernuansa agama, karena terdapat pemahaman yang ekstrem terhadap paham keagamaan sehingga melahirkan tindakan kekerasan yang justru menjadi kontraproduktif terhadap kesakralan agama itu sendiri. Sehingga dalam kondisi tertentu, menempatkan Islam dan umat Islam menjadi pihak tertuduh dengan mendapatkan stigma negatif dan stereotif dengan muncul tuduhan Islam radikal, fundamentalis, dan teroris. Di sinilah pentingnya mengkampanyekan moderasi Islam untuk mengcounter stigma negatif tersebut. Apalagi bangsa Indonesia yang dikenal sebagai masyarakat agamis di tengah kebhinekaan, pluralitas, dan multikultural.

Riset mengenai representasi moderasi Islam dalam bingkai media massa di Indonesia pernah dilakukan oleh Riyanto (2013) yang menganalisis bagaimana pertautan media massa dan Islam. Dalam penelitiannya ditawarkan model etika profetik media massa yang dibangun di atas tiga prinsip utama, yakni ketuhanan, kemanusiaan dan kebudayaan sebagai modal dalam mengkonstruksi wajah Islam 
di media massa. Penelitian Qudratullah (2017) yang memfokuskan pada kajian seputar jurnalistik Islami di media massa. Baginya, seorang jurnalis tidak sebatas penyampai informasi saja, tetapi juga sebagai penyebar kebajikan. Dalam konteks dakwah, apa yang dilakukan oleh jurnalis merupakan bagian dari dakwah bil kitabah, yakni dakwah yang dilakukan melalui tulisan sebagai medium dalam menyampaikan risalah Islam. Penelitian Aziz (2017) yang meneropong tantangan media massa Islam di era global. Aziz menganalisis bagaimana fenomena dakwah yang dilakukan di era new media sebagai output globalisasi teknologi. Disimpulkan bahwa era globalisasi menjadi tantangan bagi para pelaku media massa di Indonesia untuk terus menampilkan wajah Islam yang selaras dan universal sebagai manifestasi doktrin rabmatan lil alamin. Penelitian Sri Rizki (2018) yang menganalisis peran media massa sebagai medium reaktualisasi peradaban Islam. Disimpulkan bahwa surat kabar sebagai salah satu media massa sentral bagi manusia memiliki peran signifikan sebagai media yang mampu menjembatani kemajuan peradaban Islam. Sebab, dalam hal ini, surat kabar menjadi saluran informasi dalam mengedukasi dan meningkatkan minat literasi masyarakat Islam.

Representasi wajah Islam di media massa pernah diramaikan oleh adanya Aksi Bela Islam (ABI) yang terjadi di penghujung tahun 2016. Beberapa penelitian yang mengambil isu Aksi Bela Islam dan kaitannya dengan moderasi Islam di Indonesia dilakukan oleh Pradipta, Nur Hidayah, Haya, Ervania \& Kristanto (2018). Penelitian berkaitan dengan pembingkaian pemberitaan Aksi Bela Islam pada bulan Desember 2016 di media BBC dan REPUBLIKA. Dihasilkan bahwa analisis pembingkaian dapat memberi gambaran bagaimana signifikansi peristiwa tertentu mendorong agensi berita untuk membentuk perspektif tertentu melalui pembingkaian. Penelitian lainnya dilakukan oleh Budiasa (2017) yang merekam peristiwa Aksi Bela Islam dalam perspektif media. Hasil penelitiannya menunjukkan bagaimana mediatisasi mampu memerankan politik ketakutan dan mengkonstruksi media massa dalam memberitakan Aksi Bela Islam pada Desember 2016.

Asumsi mengenai wacana islamophobia dan pelemahan Islam di media Massa menjadi isu strategis yang seringkali dibingkai dan diberitakan. Dalam hal ini, penerapan dakwah Islam berbasis moderasi di media massa menjadi kontra narasi yang strategis untuk diinformasikan. Mengenai hal ini, analisis kajian tentang bagaimana penyetiran opini publik di media massa yang dianggap sebagai bagian dari implementasi teori konspirasi untuk melemahkan Islam. Peran media massa dalam menyebarkan isu-isu bernada konspiratif begitu penting untuk memengaruhi logika dan tindakan umat Islam penelitian (Wanodya, 2018). Konspirasi media massa ini berkaitan dengan merebaknya wacana islamophobia di media massa, terutama pasca tragedi WTC 9/11. Kecurigaan dunia barat terhadap Islam dan umat Islam memunculkan polemik dan kekhawatiran dari 
masyarakat non muslim. Hal ini berimplikasi pada adanya tuduhan terhadap doktrin Islam sebagai agama perang dan kekerasan serta umat Islam yang mencintai konflik. Dalam kasus Indonesia, tidak sedikit media massa yang terjebak pada isu islamophobia, sehingga mendiskreditkan Islam dan umat Islam (Amalia \& Haris, 2019). Wacana islamophobia di media massa Indonesia didominasi oleh pemberitaan seputar isu-isu terorisme dan radikalisme yang notabene dilekatkan dengan Islam dan umat Islam.

Dominasi pemberitaan yang berkaitan dengan isu radikalisme dan terorisme Islam di media massa perlu mendapat perhatian dari berbagai kalangan umat Islam. Hal ini berkaitan dengan konsep dakwah Islam yang mensyaratkan adanya pencitraan wajah Islam yang universial, penuh kasih sayang dan mencintai perdamaian. Kontra narasi radikalisme dan terorisme dilakukan melalui konsep moderasi Islam (Faiqah \& Pransiska, 2018). Dalam konteks kebangsaan dan kenegaraan, Indonesia merupakan negara demokrasi yang memberikan peluang kepada setiap warganya untuk berperan dalam setiap momentum pembangunan. Media massa sebagai salah satu pilar demokrasi memiliki pengaruh signifikan dalam berbagai sendi kehidupan kebangsaan. Dalam hal ini, media massa dapat dimanfaatkan sebagai medium dalam menampilkan harmonisasi Islam, umat Islam dan local wisdom yang ada di negara Indonesia. Pada titik inilah Islam rabmatan lil alamin menjadi doktrin dalam menguatkan moderasi Islam di Indonesia (Amin, 2020).

Penelitian ini lebih terfokus pada pengkajian terhadap narasi moderasi Islam Indonesia dengan mengambil fokus penelitian peran media cetak Koran Republika dalam narasi moderasi Islam Indonesia. Penelitian ini diharapkan dapat memperkuat narasi moderasi Islam Indonesia yang harus menjadi agenda bersama dalam upaya mereduksi kekerasan bernuansa agama yang kerapkali terjadi di Indonesia. Sehingga, proses pembinaan dalam pengamalan kehidupan beragama masyarakat yang ramah, rukun, damai, dan harmonis selaras dengan nilai-nilai yang terkandung dalam narasi moderasi Islam Indonesia.

Penelitian bertujuan untuk menganalisis peran media cetak dalam konstruksi narasi moderasi Islam Indonesia. Hal ini sebagai upaya untuk mereduksi kasus-kasus kekerasan bernuansa agama, sehingga tidak sedikit yang mengarah pada upaya konflik, perpecahan dan disintegrasi bangsa. Selain itu, penelitian diharapkan mampu memperkaya khazanah keilmuan terutama dalam studi agama mengenai upaya yang dapat dilakukan untuk mereduksi tindakan kekerasan bernuansa agama dengan menyebarkan dan menguatkan narasi moderasi Islam Indonesia. Penguatan narasi moderasi Islam Indonesia dipandang penting sebagai upaya memediasi pemikiran-pemikiran yang dipandang ekstrem seperti paham radikal dan liberal, yang tidak mencerminkan esensi ajaran Islam rabmatan lil alamin. 
Penelitian kualitatif dengan metode deskriptif dimaksudkan untuk mengkaji fenomena publikasi narasi moderasi Islam Indonesia yang disajikan di dalam Koran Republika periode 2017-2019. Hal ini menjadi fenomena yang cukup menarik untuk dicermati, karena terdapat situasi yang anomali. Hal ini dapat dilihat dari banyaknya tindakan kekerasan yang bernuansa agama sehingga muncul stigma teroris, fundamentalis, radikal, garis keras dan yang lainnya; tetapi pada saat yang bersamaan terkandung sisi humanis dari ajaran agama Islam yang penuh kedamaian, toleransi, dan keharmonisan. Sehingga narasi moderasi Islam Indonesia melalui media cetak ini menjadi signifikan sebagai media kontra narasi stigma-stigma negative terhadap ajaran Islam di Indonesia. Selain itu, media cetak Koran Republika sepanjang periode 2017-2019 banyak menyajikan pemberitaan mengenai narasi moderasi Islam Indonesia untuk meluruskan pemahaman tentang keislaman yang komprehensif, sekaligus sebagai ruang produksi wacana dalam melawan Islamophobia di Indonesia.

\section{HASIL DAN PEMBAHASAN}

\section{Republika dan Berita Moderat}

Media cetak Koran Republika dipandang dapat merepresentasikan kepentingan Islam dan umat Islam, khususnya di Indonesia. Karena dilihat dari latar belakang lahirnya, bahwa kelahiran Koran Republika digagas oleh tokoh-tokoh Islam Indonesia yang pada waktu itu bergabung dalam wadah Ikatan Cendekiawan Muslim Indonesia (ICMI). Kemudian segmen pembacanya mayoritas Muslim perkotaan yang berpikir modern dan moderat. Juga dalam pilihan rubriknya terdapat rubrik yang menyiarkan Islam, mempromosikan semangat toleransi, dan idealisme untuk mewujudkan Islam rahmatan lil-'alamin (Kasman, 2010:179). Dari sini dapat dipahami, bahwa Koran Republika dapat dipandang sebagai media representasi yang mempublikasikan syiar Islam dan kepentingan umat Islam Indonesia yang memiliki kekhasan moderat.

Koran Republika dipandang sebagai media yang representatif untuk mempublikasikan narasi moderasi Islam Indonesia. Menurut Eriyanto (2018:113), bahwa istilah representasi menunjuk pada bagaimana seseorang, satu kelompok, gagasan atau pendapat tertentu ditampilkan dalam pemberitaan. Representasi ini penting dalam dua hal, pertama, apakah seseorang, kelompok, atau gagasan tersebut ditampilkan sebagaimana mestinya; kedua, bagaimana representasi tersebut ditampilkan dalam pemberitaan kepada khalayak.

Gagasan yang ditampilkan dalam wacana pemberitaan adalah moderasi Islam Indonesia. Kemudian gagasan ini ditampikan sedemikian rupa dalam pemberitaan Koran Republika kepada khalayak dari mulai konsepsi, urgensi, dan implementasi moderasi Islam dalam kehidupan berbangsa dan beragama. Maka tersedialah realitas berupa dokumen teks pemberitaan mengenai moderasi Islam yang dimuat dalam Koran Republika. Jadi inti dari representasi itu adalah 
bagaimana realitas atau objek tertentu ditampilkan.

Representasi ini bekerja melalui tiga tahapan. Pertama, bagaimana elemenelemen realitas ditandakan secara teknis dalam bentuk bahasa tulis seperti kata, proposisi, kalimat, foto, grafik, dan sebagainya. Kedua, elememen-elemen tersebut ditransimisikan ke dalam kode representasional yang memasukkan bagaimana objek digambarkan seperti karakter, narasi, setting, dialog, dan sebagainya. Ketiga, bagaimana semua elemen tersebut diorganisir ke dalam konvensi-konvensi yang diterima secara ideologis (Eriyanto, 2018:115).

Sebagai media cetak yang mayoritas pembacanya berbasis Muslim perkotaan, maka Koran Republika ini memiliki peran yang signifikan dalam menyebarluaskan dan membentuk opini publik tentang keislaman yang positif dan konstruktif di tengah-tengah masyarakat. Karena dengan adanya kasus-kasus kekerasan bernuansa agama, terkadang menyudutkan dan memberikan stigma negatif kepada kelompok agama tertentu. Padahal hal itu hanya perbuatan oknum atau sekelompok orang yang tidak merepresentasikan arus utama penganut agama pada umumnya. Di sini peran Koran Republika untuk menetralisir dan meluruskan sitgma-stigma negatif tersebut dengan menyuguhkan pemberitaan secara objektif dengan didasari pandangan keagamaan yang moderat.

Para pakar komunikasi banyak merinci tentang peran media massa yang dikaitkan dengan fungsinya yang demikian kuat dan signifikan dalam kehidupan. Seperti disebutkan Effendy (1993: 27) bahwa di antara fungsi media massa adalah sosialisasi atau pemasyarakatan. Artinya penyediaan sumber ilmu pengetahuan yang memungkinkan orang bersikap dan bertindak sebagai anggota masyarakat yang memiliki kesadaran akan fungsi sosialnya sehingga dapat aktif di dalam masyarakat. Fungsi ini disebut juga oleh Elvinaro Ardianto (2007) sebagai fungsi transmission of values (penyebaran nilai-nilai). Artinya bisa saja media mewakili kita dengan model peran yang kita amati dan harapan untuk menirunya.

DeVito menyatakan bahwa fungsi media massa adalah to persuade (meyakinkan). Persuasi atau meyakinkan itu bisa dapat bentuk: (1) mengukuhkan atau memperkuat sikap, kepercayaan atau nilai sesorang; (2) mengubah sikap, kepercayaan atau nilai seseorang; (3) menggerakkan seseorang untuk melakukan sesuatu; (4) memperkenalkan etika atau menawarkan sistem nilai tertentu (Ardianto, 2007:20).

Apabila dikaitkan dengan proses komunikasi dakwah, maka media massa dapat berperan sebagai media dakwah. Karena dalam perspektif komunikasi dakwah, dapat dikatakan sebagai proses komunikasi persuasif, yang berarti membujuk, mengajak, atau merayu. Persuasif dapat diartikan sebagai proses memengaruhi pendapat dan tindakan orang dengan menggunakan manipulasi psikologis sehingga orang tersebut bertindak atas kehendaknya sendiri. Akibat 
yang ditimbulkan dari kegiatan persuasif ini adalah sebuah nilai kesadaran, kerelaan disertai perasaan senang. Sehingga dampak dari fungsi persuasif ini meliputi kognitif (pengetahuan), afektif (perasaan), dan behavioral (perbuatan) secara bersamaan (Ilaihi, 2010:125).

Media massa yang beredar dan bersentuhan dengan masyarakat adalah media cetak yang terdiri dari koran dan majalah. Sekalipun sekarang ini oplah koran dan majalah semakin menurun seiring dengan perkembangan media sosial yang masif, tetapi keberadaannya masih tetap eksis dan memiliki pengaruh pada khalayak dalam menyampaikan informasi dan edukasi kepada masyarakat. Hal ini dapat dilihat dari fungsi surat kabar atau koran dan majalah. Menurut Ardianto (2007:108) bahwa di antara fungsi yang menonjol dari koran adalah informasi, karena di antara kebutuhan khalayak membaca koran yaitu keingintahuan terhadap peristiwa yang terjadi di sekitarnya, maka sebagian besar rubrik koran berisi informasi. Meskipun tidak dapat menafikan fungsi-fungsi lainnya yaitu edukasi, rekreasi dan persuasi yang tetap menghiasi rubrik dalam surat kabar atau koran. Juga majalah pun memiliki fungsi menonjol sebagai media informasi dan edukasi terhadap khalayak. Ini sangat bergantung kepada jenis dan karakteristik majalahnya. Tetapi pada intinya majalah memiliki fungsi memberikan informasi dan pendidikan kepada masyarakat untuk meningkatkan pengetahuan dan pengalamannya.

Apabila dihubungan dengan tatanan kehidupan masyarakat, media massa, termasuk di dalamnya media cetak, memiliki peran yang signifikan. Vivian (2008: 503) merinci beberapa peran media massa dalam masyarakat, yaitu: (1) Media massa berperan mendorong kultur kreatif, sehingga bagi orang kreatif media massa dapat menjadi sarana untuk menyalurkan dan mempublikasikan ide dan praktek kreatifnya; (2) Media massa berperan memberi kontribusi pada stabilitas sosial dengan menciptakan ritual yang dijalani orang dalam kehidupan seharihari, juga memberi kontribusi pada kohesi sosial dengan mengafirmasi keyakinan dan nilai-nilai dan menjembatani diskrepansi antara perilaku privat dengan moralitas publik; (3) Media massa berperan sebagai agenda-setter, dalam arti media dapat menarik pada satu persoalan yang membantu terjadinya kohesi sosial karena membuat perhatian kolektif pada isu yang bisa dibahas bersama; (4) Media massa berperan mentransmisikan nilai-nilai kultural melalui sejarah, generasi-generasi terdahulu berbicara kepada kita melalui media massa, dan kita akan berbicara kepada generasi masa depan melalui media massa, media massa juga menyebarkan nilai dan gagasan yang ada pada zamannya masing-masing; (5) Media massa berperan melakukan perubahan secara fundamental dari kultur komunikasi interpersonal kepada komunikasi lewat tulisan yang menggunakan pikiran, kemudian televisi menggantikan komunikasi tertulis sehingga terjadilah retribalisasi dan melahirkan desa global.

Dalam konteks ini, pers atau surat kabar memiliki kekuatan dan peran yang 
tidak kecil untuk membentuk pendapat umum (public opinion). Sebab, tidak ada gagasan pribadi yang dapat berubah menjadi pendapat umum, tanpa melalui proses publikasi, di antaranya melalui media surat kabar (Muhtadi, 1999:53). Peran ini tidak lepas dari fungsi media cetak termasuk di dalamnya koran yang memiliki fungsi utama menyiarkan informasi melalui berita-berita yang disajikannya. Kemudian surat kabar pun berfungsi sebagai sarana pendidikan untuk menambah pengetahuan khalayak dengan menampilkan artikel-artikel yang berbobot; berfungsi untuk menghibur dengan menyajikan cerita-cerita, teka-teki, dan karikatur; juga berfungsi untuk mempengaruhi sehingga terjadi perubahan pendapat, sikap dan tindakan dalam masyarakat karena pengaruh media cetak surat kabar.

Media cetak, di antaranya surat kabar sesuai dengan sifat yang dimilikinya, selalu menyajikan informasi yang terbaru bagi pembacanya. Informasi yang disajikan di samping bersifat aktual, juga menyebarkan opini atau ide-ide yang dianggap baru dan relevan dengan kondisi masyarakat di mana surat kabar itu menyebar. Nilai aktualitas ini disajikan melalui kemasan artikel-artikel yang merupakan hasil analisis para pakar di bidangnya, maupun rubrik tajuk rencana yang dibuat oleh redaktur untuk mengulas berita utama yang sedang terjadi dan menjadi perbincangan umum dalam masyarakat. Rogers menyebutkan bahwa ide-ide baru itu sebagai inovasi, yaitu gagasan, tindakan, atau barang yang dianggap baru meskipun diukur secara subjektif menurut pandangan individu yang menerimanya (Muhtadi, 1999:45).

Di antara pemberitaan yang mendapatkan porsi untuk disajikan dalam Koran Republika yaitu mengenai wacana atau narasi moderasi Islam. Pemberitaan ini tentunya membentuk dan mempengaruhi opini publik sehingga memberikan pencerahan kepada masyarakat tentang pentingnya pemahaman dan penguatan moderasi Islam untuk menampilkan wajah Islam yang ramah dan damai (rabmatan lil alamin).

Maka dalam konteks wacana atau narasi moderasi Islam, yang harus dimoderasi itu bukan Islamnya, tetapi cara berislamnya. Sehingga umat Islam tidak terjebak pada pemahaman yang keliru dan ekstrem, sehingga melakukan tindakan kekerasan dan pengrusakan yang sebenarnya tidak dibenarkan oleh ajaran Islam itu sendiri. Di sinilah pentingnya penguatan wacana atau narasi moderasi Islam Indonesia melalui media cetak.

Kalau coba ditelusuri, bahwa terminologi moderasi diadaptasi dari Bahasa Arab yang berasal dari kata al-wasthiyyah atau at-tawazun, artinya keseimbangan di antara dua jalan yang saling berhadapan. Menurut Qardhawi (1995:155), bahwa karakteristik ajaran Islam yang wasathiyah (moderat) ini sesuai dengan hakikat penciptaan alam semesta yang diciptakan secara adil dan seimbang. Sehingga dengan keseimbangan ini menjadikan sistem tata surya dalam jagat raya ini 
Dudung Abdul Rohman

bersifat selaras dan harmonis. Ajaran Islam yang dibawa oleh Nabi Muhammad saw pun selaras dengan fitrah (penciptaan) manusia yang menghendaki terwujudnya kedamaian dan keharmonisan dalam kehidupan.

Sebelum Islam datang, pada waktu itu terdapat penganut agama Yahudi yang lebih cenderung materialisme (maddiyah), dan penganut agama Nasrani yang lebih berorientasi pada spiritualisme (rubiyah). Penganut agama Yahudi lebih cenderung mengekang dengan banyak pengharaman-pengharaman, bahkan bersikap ekstrem dengan merubah kitab-kitab suci serta membunuh para nabi dan rasul. Sedangkan penganut agama Nasrani lebih cenderung mempermudah dengan banyak penghalalan-penghalalan, bahkan bersikap ekstrem dengan mengakui Tuhan memiliki anak. Maka Islam datang untuk menyeimbangkan dua kutub kecenderungan beragama yang ekstrem tersebut dengan menjadikannya sebagai ummatan wasathan, umat pertengahan, pilihan atau terbaik. Inilah keistimewaan umat Islam yang menjadi umat pertengahan dengan sistem (manhaj) yang serasi dan seimbang, yang selamat dari kekurangan atau melebihlebihkan (ekstrem). Dalam Alquran Surat Al-Baqarah [2] ayat 143 Allah SWT berfirman:

Artinya: "Dan demikian (pula) Kami telah menjadikan kamu (umat Islam), umat yang adil dan pilihan agar kamu menjadi saksi atas (perbuatan) manusia dan agar Rasul (Muhammad) menjadi saksi atas (perbuatan) kamu. Dan Kami tidak menetapkan kiblat yang menjadi kiblatmu (sekarang) melainkan agar Kami mengetahui (supaya nyata) siapa yang mengikuti Rasul dan siapa yang membelot. Dan sungguh (pemindahan kiblat) itu terasa amat berat, kecuali bagi orang-orang yang telah diberi petunjuk oleh Allah; dan Allah tidak akan menyia-nyiakan imanmu. Sesungguhnya Allah Maha Pengasih lagi Maha Penyayang kepada manusia" (Kementerian Agama, 2014:22).

Kemudian Qardhawi (1996) merinci makna wasathiyah (moderasi) itu bisa bermakna adil, istiqamah, kebaikan, keamanan, kekuatan, dan kesatuan. Juga makna wasathiyah ini tercermin dalam keseluruhan ajaran Islam, baik dalam akidah (keimanan), ibadah (ritual keagamaan), maupun akblak (perilaku dan perbuatan). Maka dalam Islam, dapat dikatakan tidak ada tempat untuk berbuat berlebih-lebihan dalam beragama (ekstrem). Tetapi Islam memerintahkan untuk senantiasa adil dan seimbang dalam memperlakukan kehidupan. Misalnya Islam memerintahkan untuk bersikap adil, karena adil itu berada di tengah antara kecenderungan ke sebelah kanan dan kiri. Islam memerintahkan untuk bersikap berani, karena berani itu berada di antara sikap pengecut dan sembrono. Islam pun memerintahkan untuk bersifat dermawan, karena dermawan itu berada di antara sifat kikir dan boros.

Konsepsi moderasi Islam ini menjadi urgen untuk terus digelorakan, 
karena dewasa ini umat Islam dihadapkan pada satu propoganda yang tidak proporsional (seimbang). Bahwa posisi umat Islam dipojokkan dengan adanya peristiwa-peristiwa radikalisme, terorisme, dan anarkisme atas nama agama. Dalam kondisi ini, umat Islam harus kembali pada posisi ummatan wasathan, umat pertengahan yang dapat menjadi penengah di antara arus kebebasan dan keterbukaan sebagai dampak dari revolusi industri dan era globalisasi yang sulit untuk dikendalikan. Menurut Taher (2007:145), bahwa di tengah arus perubahan dan kebebasan, ummatan wasathan harus memiliki tiga ciri utama, yaitu: (1) Adanya hak kebebasan yang harus selalu diimbangi dengan kewajiban; (2) Adanya keseimbangan antara kehidupan duniawi dan ukhrawi, serta material dan spiritual; dan (3) Adanya keseimbangan yang terwujud pada pentingnya kemampuan akal dan moral.

Menurut Lukman Hakim Saifuddin (2019) sekurangnya terdapat 3 alasan mengapa moderasi Islam ini penting: pertama, salah satu esensi kehadiran agama, termasuk Islam, adalah untuk menjaga martabat manusia sebagai makhluk mulia ciptaan Tuhan, maka setiap agama selalu membawa misi damai dan keselamatan. Kedua, ribuan tahun setelah Islam lahir dan menyebar ke seluruh pelosok negeri yang beragam suku bangsa, etnis, bahasa, dan budaya, sehingga memunculkan beragam tafsir terhadap teks-teks agama yang terkadang menimbulkan konflik, maka di sini pentingnya moderasi Islam supaya peradaban manusia tidak musnah akibat konflik berlatar agama. Ketiga, moderasi beragama yang di dalamnya juga terdapat moderasi Islam sebagai strategi kebudayaan dalam merawat keindonesiaan. Indonesia disepakati bukan negara agama, tetapi juga tidak memisahkan agama dari kehidupan warganya. Nilai-nilai agama dijaga, dipadukan dengan nilai-nilai kearifan lokal, beberapa hukum agama dilembagakan oleh negara, ritual agama dan budaya berjalin berkelindan dengan rukun dan damai (Kementerian Agama, 2019:10).

Din Syamsuddin (2018) menjelaskan bahwa moderasi Islam (wasthiyatul Islam) adalah suatu corak pemahaman dan pengalaman Islam. Wasatbiyah pun merupakan suatu metode atau pendekatan dalam mengkontekstualisasi Islam di tengah peradaban global. Kehadiran moderasi Islam sangat perlu dan dibutuhkan baik di lingkungan umat Islam sendiri, maupun di tengah pergulatan Islam dengan beragam agama dan sistem dunia lainnya. Selanjutnya dia mengemukakan, bahwa pemahaman dan praksis keislaman wasathiyah menjadi keniscayaan di tengah tantangan krisis di banyak bagian Dunia Muslim dan peradaban dunia yang disebabkan pemahaman dan praksis keagamaan yang tidak wasathiyah dan perkembangan dunia yang tidak berkeseimbangan dalam berbagai aspek kehidupan seperti politik, ekonomi, sosial-budaya, sains-teknologi, ilmu pengetahuan, lingkungan hidup, dan lain-lain. Wasthiyyatul Islam (moderasi Islam) juga mendorong adanya islah (reformasi) peradaban sebagaimana makna 
yang terkandung di dalamnya. Agenda membangun peradaban dunia lebih damai, berkeadilan dan berkeseimbangan merupakan agenda Wasathiyah Islam baik di Dunia Muslim maupun lingkungan internasional yang lebih luas (Kantor Utusan Khusus Presiden, 2018: 8).

Moderasi Islam sebagai sebuah metode berpikir, berinteraksi dan berperilaku yang didasari atas sikap tawazun (seimbang) dalam menyikapi dua keadaan perilaku yang dimungkinkan untuk dibandingkan dan dianalisis, sehingga dapat ditemukan sikap yang sesuai dengan kondisi dan tidak bertentangan dengan prinsip-prinsip ajaran agama dan tradisi masyarakat. Yang menjadi landasan dari moderasi Islam ini, menurut Muchlis M. Hanafi, adalah keadilan (al-adalab), keseimbangan (al-tawarun), dan penghormatan (al-tasamub). Sedangkan ciri-cirinya adalah: (1) Memahami realitas (fahm al-waqi); (2) Memahami fiqih prioritas (fahm fiqh al-auliyaat); (3) Menjauhkan dari fanatisme yang berlebihan (al-bu'd 'an al-ta'ashub al-zaidab); (4) Mendahulukan prinsip kemudahan dalam beragama (taqdim mabda' al-taisiir fi al-tadyin); (5) Memahami teks-teks agama secara komprehensif (fahm nushuus al-diin bi thariqati syaamilab); (6) Terbuka dan lapang dada dalam mensikapi perbedaan (al-sharahah wa alsyafafiyah fi mawaajihat al-ikhtilaaf); dan (7) Bersepakat dalam kebenaran dan keadilan (al-ittifaq 'ala al-haq wa al-'adaalab) (Hanafi, 2018).

Moderasi Islam ini harus diimplementasikan dalam kehidupan bermasyarakat supaya tercipta kerukunan dan kedamaian. Terutama dalam konteks kehidupan bangsa Indonesia yang plural dan muntikultural, baik suku bangsa, budaya, bahasa, dan agama. Apalagi belakangan ini acapkali terjadi kasuskasus kekerasan bernuansa agama yang dapat mengancam disintegrasi bangsa. Maka sebagai implementasi dari moderasi Islam dalam kehidupan berbangsa dan beragama, maka perlu ditunaikan hak dan kewajiban pemeluk-pemeluk agama dalam kehidupan bermasyarakat. Menurut Hanafi (2018), bahwa di antara wujud dari implementasi moderasi Islam adalah menjaga hak-hak beragama dalam kehidupan bermasyarakat, yaitu: (1) Hak manusia untuk mendapatkan keamanan dan kedamaian; (2) Hak untuk bermasyarakat secara baik; (3) Hak untuk membina ketentraman dalam beribadah sesuai dengan keyakinannya; dan (4) Hak persamaan dan keadilan.

Representasi moderasi Islam dalam Koran Republika digambarkan melalui serangkaian pemberitaan yang menguatkan basis dan komitmen dalam aktualisasi nilai rahmatan lil alamin. Hal ini dapat dilihat dari beberapa pemberitaan seputar moderasi Islam yang diterbitkan Koran Republika sepanjang tahun 2017-2019. Narasi moderasi Islam Indonesia ini disampaikan melalui proses dan teknis pemberitaan yang didalamnya merepresentasikan wajah Islam Indonesia baik secara kelembagaan maupun figuritas personal. Pada sudut kelembagaan, institusi agama seperti Kementerian, Pesantren, Ormas Islam dan Lembaga Pendidikan Islam menjadi sentra Koran Republika dalam menguatkan narasi 
moderasi Islam Indonesia. Misalnya, pemberitaan yang merujuk pada sumber kementerian agama RI. Pernyataan seputar moderasi Islam yang berasal dari Menteri Agama RI, Lukman Hakim Saifuddin sering dijadikan sebagai rujukan dalam beberapa pemberitaan Koran Republika. Selain itu, representasi narasi moderasi Islam Indonesia dalam pemberitaan Koran Republika terdeskripsikan melalui setting dialog, kode representasional dan konvensi ideologis yang menyatu dengan visi Koran Republika sebagai media Islam moderat di Indonesia.

Pada sudut figuritas personal, pemberitaan mengenai moderasi Islam Indonesia di Koran Republika dapat dilihat dari pengutipan dari beberapa tokoh umat Islam Indonesia yang memiliki konsentrasi dalam mengimplementasikan nilai-nilai toleransi, perdamaian dan persatuan. Tokoh-tokoh seperti Ustadz Tanjung, Quraish Shihab, Syafii Maarif, Din Syamsuddin, dan lain sebagainya dianggap sebagai tokoh sentral dalam aktualisasi isu moderasi Islam Indonesia. Figuritas personal ini menunjukkan bagaimana konsep moderasi Islam di Indonesia menjadi isu strategis yang dikonstruksi oleh media massa seperti Koran Republika.

Kontra narasi radikalisme dan terorisme yang belakangan menjadi isu sensitif bagi umat Islam di Indonesia, dilakukan melalui penguatan narasi moderasi Islam. Media massa sebagai salah satu pilar negara demokrasi, memiliki peran siginifikan sebagai ruang publik yang memproduksi dan menyebarkan wacana moderasi keberislaman. Dalam perspektif dakwah, apa yang dilakukan oleh Koran Republika dalam mewacanakan moderasi Islam Indonesia menunjukkan tingkat signifikansi kegiatan dakwah yang memanfaatkan teknologi komunikasi dan informasi (Mamdud, 2019: 50-52). Koran Republika menjadi media yang berupaya mengedukasi dan mempersuasi khalayak Indonesia agar semakin sadar tentang pentingnya konsep rabmatan lil alamin dalam perikehidupan kebangsaan dan kenegaraan. Upaya ini diwujudkan dalam kerangka menjaga harmonisasi kehidupan antar berbagai elemen bangsa, sekaligus meminimalisir upaya-upaya yang dilakukan oleh beberapa 'oknum' untuk memecahbelah bangsa.

Era globalisasi, pemanfaatan media massa seperti koran, televisi dan media internet menjadi penting sebagai upaya menjaga agar dakwah Islam senantiasa kontekstual dan rasional. Dalam hal ini, seorang juru dakwah memiliki kewajiban untuk terus mengupdate informasi dan menguasai keterampilan teknologis sehingga mampu menyebarkan nilai-nilai ajaran Islam dalam kerangka gerakan dakwah yang lebih luas. Salah satu alasan mengapa Islam mudah diterima adalah karena nilai-nilai moderasi yang dipandang mampu memenuhi kebutuhan dan kemashlahatan umat. Ajaran moderat harus ditumbuhkembangkan di era globalisasi ini oleh gerakan dakwah dengan tiga instrumen utama yakni 
substansialisasi ajaran, kontekstualisasi ajaran, dan rasionalisasi ajaran (Al-Rasyid, 2014: 12).

Koran Republika melakukan persuasi khalayak untuk memahami pentingnya persatuan dan kesatuan dalam membangun keutuhan umat. Proses persuasif ini dilakukan melalui rasionalisasi ajaran Islam dalam konsep moderasi Islam di Indonesia. Sehingga, melalui pemberitaan yang berkaitan dengan narasinarasi moderasi Islam dapat menyadarkan kahalayak mengenai pentingnya menghindari permusuhan dan konflik atas nama agama sebagai bentuk tanggung jawab keislaman, keindonesiaan dan kemanusiaan. Koran Republika melalui pemberitaan moderasi Islam dipandang merepresentasikan media Islam moderat yang berorientasi pada penguatan keutuhan umat Islam secara internal dan menampilkan wajah Islam yang universal, rahmatan lil alamin.

\section{Pemberitaan Moderasi Dakwah Islam Koran Republika}

Media cetak Koran Republika memiliki peran yang signifikan dalam menyebarkan narasi moderasi Islam Indonesia. Selain karena Republika merupakan surat kabar komunitas Muslim, juga karena Republika memiliki visi menyiarkan Islam yang moderat dan rabmatan lil'alamin demi menjaga persatuan dan kesatuan bangsa. Berdasarkan temuan penelitian, sepanjang periode 2017 2019, Koran Republika secara berkala mempublikasikan artikel berita tentang narasi moderasi Islam Indonesia. Ini dapat dilihat dalam tabel berikut ini:

Tabel 1.

Artikel Narasi Moderasi Islam Indonesia Dalam Koran Republika Periode 2017

\begin{tabular}{|c|c|c|}
\hline No. & Tanggal & Judul \\
\hline 1 & 03 Maret 2017 & $\begin{array}{l}\text { Menag: Arab-Indonesia Sepakat Jaga Moderasi } \\
\text { Islam }\end{array}$ \\
\hline 2 & 17 Mei 2017 & $\begin{array}{l}\text { Kemenag Kembangkan Pengabdian Untuk } \\
\text { Moderasi Islam }\end{array}$ \\
\hline 3 & 19 Oktober 2017 & $\begin{array}{l}\text { Habib Umar Al-Hafizh Bekali Dosen PAI } \\
\text { Tentang Moderasi Islam }\end{array}$ \\
\hline 4 & 09 November 2017 & $\begin{array}{l}\text { Kemenag Bentuk Pusat Kajian Moderasi Islam } \\
\text { dan Universitas }\end{array}$ \\
\hline 5 & 14 November 2017 & $\begin{array}{l}\text { Bertemu WNI di Jepang, Menag bicara Moderasi } \\
\text { Islam }\end{array}$ \\
\hline 6 & 27 Desember 2017 & Kemenag Kumpulkan Kiai Pesantren \\
\hline
\end{tabular}

Sumber: Observasi Penulis 2019

Tabel 1 menunjukkan beberapa artikel tentang moderasi Islam yang dimuat oleh Koran Republika pada tahun 2017. Setidaknya ada 6 artikel utama 
dalam bentuk straight nesws yang membahas mengenai wacana moderasi Islam di Indonesia. Sepanjang tahun 2017, Koran Republika memberitakan wacana moderasi Islam baik menggunakan sumber rujukan yang bersifat institusional maupun figuritas personal. Pemberitaan wacana moderasi Islam dibingkai melalui penguatan konsepsi, jejaring moderasi antar negara dalam konteks global, penguatan basis-basis kelembagaan yang menjadi sentral moderasi Islam seperti pesantren dan Universitas, serta melalui penggambaran yang disampaikan oleh tokoh baik itu ustadz, ulama, cendekiawan maupun kalangan birokrat seperti Menteri Agama.

Narasi wacana moderasi Islam dalam pemberitaan Koran Republika ditampilkan melalui serangkaian pesan komunikasi yang bertujuan mengedukasi dan mempersuasi khalayak. Persuasi ini dilakukan baik secara kognitif, afektif maupun behavioural. Sehingga, narasi moderasi Islam di Indonesia menjadi pesan kemanusiaan yang dapat menyadarkan dan menguatkan nilai-nilai universalitas Islam dalam kerangka dakwah Islam. penguatan nilai-nilai universal keislaman ini sebagai upaya dalam membangun peradaban Islam yang dapat mengakomodir kebutuhan khalayak keummatan, sekaligus menjadi ruang untuk mencapai kemashlatan bersama.

Tabel 2.

Artikel Narasi Moderasi Islam Indonesia Dalam Koran Republika Periode 2018

\begin{tabular}{lll}
\hline No. & Tanggal & Judul \\
\hline 1 & 05 Februari 2018 & $\begin{array}{l}\text { Seribu Tahun Al-Azhar dan Menteri Lukman } \\
\text { Sebagai Garda Depan Moderasi Islam, Ini } \\
\text { Kelebihan Madrasah }\end{array}$ \\
3 & 24 Maret 2018 & $\begin{array}{l}\text { Indonesia dan Arab Sepakat Sosialisasi Islam } \\
\text { Washatiyah }\end{array}$ \\
4 & 31 Maret 2018 & $\begin{array}{l}\text { Menag: Keseimbangan dan Keadilan Kunci } \\
\text { Moderasi Islam }\end{array}$ \\
5 & 21 Juni 2018 & $\begin{array}{l}\text { Indonesia Ajak Negara Islam Promosikan } \\
\text { Moderasi Agama }\end{array}$ \\
6 & 27 Juni 2018 & $\begin{array}{l}\text { Indonesia Contoh Moderasi Islam Bagi Negara } \\
\text { Lain }\end{array}$ \\
7 & 27 Juli 2018 & Pentingnya Moderasi Islam di Negara Konflik \\
\hline
\end{tabular}

Sumber: Observasi Penulis 2019

Tabel 2 merupakan artikel moderasi Islam yang dipublikasikan Republika sepanjang tahun 2018. Ada 7 artikel utama yang membahas mengenai narasi moderasi Islam. Jika kita amati, artikel tersebut menggunakan pola penulisan dan 
Dudung Abdul Rohman

kaidah jurnalistik yang sama dengan artikel pada tahun 2017. Setting narasi, dialog dan titik tekan gagasan dibingkai melalui serangkaian pesan komunikasi baik yang bersifat linguistik maupun ikonik. Dua pendekatan utama untuk menguatkan narasi moderasi Islam dilakukan baik melalui pendekatan kelembagaan maupun pendekatan figuritas personal. Hal ini sebagai upaya menampilkan citra Islam Indonesia yang moderat. Koran Republika berupaya meminimalisir tendensi dan wacana islamophobia yang didominasi oleh media barat sebagai bentuk kecurigaan dan pelemahan terhadap Islam.

Sepanjang tahun 2018, Koran Republika dengan narasi yang dikonstruksinya, ingin menguatkan posisi Indonesia di arena global sebagai negara yang aman, damai dan rukun. Sekaligus ingin menampilkan wajah Islam Indonesia sebagai role model pengembangan Islam moderat di kancah dunia. Hal ini dapat dilihat dari artikel-artikel moderasi Islam yang dipublikasikan pada tahun 2018. Dimensi moderasi Islam ini dikuatkan melalui peranan sepeti Koran Republika dalam kerangka membangun keharmonisan kemanusiaan sekaligus aktualitas nilai-nilai universal keislaman. Islam agama yang rahmatan lil alamin mengidealkan lahirnya nilai moderat pada seluruh umat, wasathiyah atau moderat berarti jalan tengah atau keseimbangan antara dua hal (Ramdhan, 2018: 45).

Tabel 3.

Artikel Narasi Moderasi Islam Indonesia Dalam Koran Republika Periode 2019

\begin{tabular}{|c|c|c|}
\hline No. & Tanggal & Judul \\
\hline 1 & 28 Februari 2019 & $\begin{array}{l}\text { Buta Aksara Keagamaan, Tantangan Besar } \\
\text { Moderasi Islam }\end{array}$ \\
\hline 2 & 05 Maret 2019 & $\begin{array}{l}\text { Menag Minta Kampus Terus Proaktif Gelorakan } \\
\text { Moderasi Islam }\end{array}$ \\
\hline 3 & 27 Maret 2019 & $\begin{array}{l}\text { Buku Putih Moderasi Beragama Panduan Semua } \\
\text { Lini Pendidikan }\end{array}$ \\
\hline 4 & 16 Mei 2019 & $\begin{array}{l}\text { Uji Sahih Buku Putih Moderasi Beragama, } \\
\text { Kemenag Undang Pakar }\end{array}$ \\
\hline 5 & 16 Mei 2019 & $\begin{array}{l}\text { Moderasi Agama Materi Penting Seleksi } 138 \\
\text { Ribu Profesi Guru }\end{array}$ \\
\hline 6 & 15 Juni 2019 & $\begin{array}{l}3 \text { Langkah Wujudkan Moderasi Beragama } \\
\text { Menurut Quraish Shihab }\end{array}$ \\
\hline 7 & 18 Juni 2019 & $\begin{array}{l}\text { Ustaz Tanjung: UIII Akan Kibarkan Bendera } \\
\text { Moderasi }\end{array}$ \\
\hline 8 & 04 Juli 2019 & $\begin{array}{l}\text { UIN Bandung Terus Gelorakan Prinsip } \\
\text { Moderasi Islam }\end{array}$ \\
\hline
\end{tabular}

Sumber: Observasi penulis 2019 
Tabel 3 adalah artikel tentang moderasi Islam yang diterbitkan Koran Republika sepanjang tahun 2019. Terdapat sekitar 8 artikel yang menjadi data analisis peneliti untuk memetakan peran media cetak dalam meguatkan narasi moderasi Islam. Penguatan narasi ini dilakukan melalui implementasi basis-basis pendidikan Islam sebagai sentral pengkajian konsep dan gagasan moderasi Islam di Indonesia. Melalui artikel-artikel tersebut, Koran Republika memposisikan sebagai elemen negara yang berperan secara positif dan konstruktif dalam menyebarluarkan pesan-pesan keislaman secara damai dan moderat. Hal ini dilakukan sebagai upaya dalam melakukan kontra narasi radikalisme dan kekerasan bernuansa agama yang belakang disudutkan kepada umat Islam. Di sini peran media cetak Koran Republika untuk menetralisir dan meluruskan sitgma-stigma negatif tersebut dengan menyuguhkan pemberitaan secara objektif dengan didasari pandangan keagamaan yang moderat.

Apa yang dilakukan oleh Koran Republika menunjukkan sikap media Islam yang terbuka dan bertanggung jawab. Koran Republika melalui artikel tentang moderasi Islam berupaya menampilkan citra Islam yang universal, harmonis dan terbuka dengan berbagai dinamika dan perkembangan zaman. Hal ini sebagai aktualisasi nilai keterbukaan dalam Islam sekaligus menunjukkan bahwa perbedaan sebagai sebuah keniscayaan yang akan terus hidup di Indonesia. sikap moderasi Islam menuntut keterbukaan, kerjasama, dan toleransi (Mubakkirah, 2018: 257-258). Pada titik inilah media massa memiliki peran signifikan dalam mempersuasi khalayak untuk menjadikan moderasi Islam sebagai nilai dan identitas muslim di Indonesia.

Pers atau surat kabar memiliki kekuatan dan peran yang tidak kecil untuk membentuk pendapat umum (public opinion). Sebab, tidak ada gagasan pribadi yang dapat berubah menjadi pendapat umum, tanpa melalui proses publikasi, di antaranya melalui media surat kabar (Muhtadi, 1999:53). Peran ini tidak lepas dari fungsi media cetak termasuk di dalamnya koran yang memiliki fungsi utama menyiarkan informasi melalui berita-berita yang disajikannya. Kemudian surat kabar pun berfungsi sebagai sarana pendidikan untuk menambah pengetahuan khalayak dengan menampilkan artikel-artikel yang berbobot; berfungsi untuk menghibur dengan menyajikan cerita-cerita, teka-teki, dan karikatur; juga berfungsi untuk mempengaruhi sehingga terjadi perubahan pendapat, sikap, dan tindakan dalam masyarakat karena pengaruh media cetak surat kabar (Effendy, 1993:92).

Pemberitaan yang mendapatkan porsi untuk disajikan dalam Koran Republika mengenai narasi moderasi Islam. Pemberitaan ini tentunya membentuk dan mempengaruhi opini publik sehingga memberikan pencerahan kepada masyarakat tentang pentingnya pemahaman dan penguatan moderasi Islam untuk menampilkan wajah Islam yang ramah dan damai (rabmatan lil- 
alamin). Dalam hal ini dapat dilihat bagaimana konstruksi media cetak Koran Republika dalam membingkai realitas sosial yang menyangkut narasi moderasi Islam Indonesia untuk mereduksi tindakan kekerasan bernuansa agama? Nampaklah komitmen dan konsistensi Koran Republika dalam memberitakan isu-isu keislaman di Indonesia. Ini sesuai dengan pencitraan dan kepercayaan publik terhadap dirinya, bahwa ia merupakan surat kabar komunitas Muslim yang selalu hadir menyiarkan berita-berita keislaman yang diproduksi secara moderat dan santun.

Seperti diketahui, bahwa kaidah penulisan berita dalam media cetak atau surat kabar secara umum mengikuti kaidah $5 \mathrm{~W}+1 \mathrm{H}$, yaitu: (1) What = apa yang terjadi; (2) Where = dimana hal itu terjadi; (3) When = kapan peristiwa itu terjadi; (4) $W$ ho = siapa yang terlibat dalam kejadian itu; (5) $W$ by = mengapa peristiwa itu terjadi; dan (6) How = bagaimana peristiwa itu terjadi. Dalam hal ini Koran Republika lebih menekankan pada pemberitaan tentang suatu event kegiatan yang dilakukan untuk narasi dan publikasi moderasi Islam Indonesia. Jadi sifatnya penyebaran informasi, sekalipun tetap diharapkan terbentuknya opini publik tentang pentingnya narasi moderasi Islam Indonesia.

Kalau melihat karakteristik berita yang disajikan, maka artikel berita tentang konsepsi moderasi Islam Indonesia ini jenisnya adalah Straight news, yakni berita langsung, apa adanya, ditulis secara singkat dan lugas. Karena yang diberitakan adalah suatu fakta dan data yang berkaitan dengan even kegiatan yang dilaksanakan. Sehingga yang diberitakan tentunya yang tercakup dan terlibat secara signifikan dalam even kegiatan tersebut. Namun untuk lebih mendalami substansi materi berita, dipaparkan juga tentang pandangan atau pendapat tokoh agama, akademisi, maupun pejabat biokrasi yang dipandang representatif, kualifikatif dan otoritatif untuk menyampaikan pandangannya mengenai konsepsi moderasi Islam Indonesia. Meskipun yang paling banyak dikutip adalah pejabat di Kementerian Agama dari mulai menterinya, pejabat eselon I (sekjen/dirjen) hingga pejabat ke bawahnya. Berarti dalam kondisi tertentu, karakteristik pemberitaannya berjenis Opinion news, yakni berita mengenai pendapat seseorang, biasanya para cendekiawan, tokoh, pejabat, tentang suatu hal, peristiwa, kondisi, dan sebagainya.

Kemudian dilihat dari aspek konstruksi berita yang disajikan, dalam hal ini Koran Republika lebih memframing (membingkai) penekanan yang positif tentang Islam wasathiyah atau moderasi Islam Indonesia. Di sini dapat dinilai, bahwa Koran Republika memandang positif dan apresiatif terhadap ide dan gagasan moderasi Islam tersebut yang dianggapnya cocok untuk kultur keislaman umat Islam Indonesia yang bersikap terbuka, toleran, dan harmonis. Juga sebaliknya, Koran Republika memframing negatif dan memandang destruktif (merusak) paham-paham yang ekstrem dalam agama seperti radikalisme dan ekstremisme apabila dibiarkan berkembang. Meskipun bisa saja konstruksi berita 
ini bersifat subjektif, yakni pihak media itu sendiri yang mengkonstruksinya sesuai dengan paradigma yang dimilikinya, tetapi hal ini dapat dilihat posisi Koran Republika yang memiliki paradigma pemikiran yang cenderung sama tentang pentingnya narasi moderasi Islam Indonesia terus digelorakan dan disebarkan.

Hal ini dapat dimaklumi, karena selama ini Koran Republika merupakan media komunitas Muslim Indonesia yang mempublikasikan aspirasi (suara) Islam dan umat Islam. Sedangkan karakteristik Muslim Indonesia menghendaki terbinannya kerukunan dan keharmonisan antarumat beragama dalam bingkai Negara Kesatuan Republika Indonesia. Artinya masyarakat Muslim Indonesia tidak menyukai tindakan-tindakan kekerasan atau anarkisme yang mengatasnamakan agama. Diperkuat lagi dengan ideologi, visi, dan misi Koran Republika yang menyiarkan Islam kosmopolitan yang berpijak pada Islam yang rahmatan lil-alamin, santun dan moderat, serta berkomitmen untuk menjaga persatuan dan kesatuan bangsa Indonesia yang plural dan multikultural. Ditambah lagi dengan tim redaktur dan jurnalis Koran Republika yang hampir seluruhnya Muslim dan memiliki komitmen keislaman dan kebangsaan. Ini semua tentunya mewarnai corak dan karakteristik pemberitaan keagamaan atau keislaman yang dipublikasikan melalui media cetak Koran Republika, termasuk di dalamnya pemberitaan narasi moderasi Islam Indonesia.

Pemberitaan mengenai narasi moderasi Islam Indonesia, posisi media cetak Koran Republika tetap konsisten sebagai agen media yang memberitakan tentang penguatan moderasi Islam dalam kehidupan berbangsa dan bernegara. Di sini dapat dilihat, bahwa moderasi Islam jangan hanya berhenti sampai jargon dan retorika yang terus diwacanakan, tetapi harus ada upaya-upaya konkrit bagaimana menerapkannya dalam kehidupan. Maka perlu ada upaya yang serius melakukan sosialisasi dan diseminasi tentang moderasi Islam ini supaya dapat membumi dan menjadi landasan moral dan etika dalam menjalankan aktivitas keseharian, termasuk bagi para pegawai Aparatur Sipil Negara (ASN) dalam menjalankan tugas dan fungsinya.

Kalau dilihat dari aspek pencitraan (perception images), dapat dilihat bahwa Koran Republika tetap konsisten mencitrakan positif tentang moderasi Islam Indonesia. Misalnya dari aspek penonjolan isu, tetap isu tentang moderasi Islam itu mendapat perhatian dan apresiasi yang positif. Juga dari aspek penekanan isu, bahwa wacana dan gagasan moderasi Islam harus mendapatkan perhatian lebih atau penekanan karena isu ini dianggap relevan untuk menghalau image negatif tentang Islam dan umat Islam, terutama yang dicitrakan oleh media Barat.

Berdasar aspek pengulangan yang merupakan persepsi jurnalis (wartawan) terhadap realitas yang terjadi, maka pemberitaan mengenai moderasi Islam ini mendapat porsi pemberitaan yang cukup memadai, terutama dalam kolom 
pembahasan isu-isu keislaman, lebih-lebih ketika terjadi tindakan kekerasan yang bernuansa agama, maka pengulangan tentang wacana moderasi Islam ini dipandang signifikan untuk mengcounter citra negatif yang dialamatkan kepada Islam dan umat Islam sehubungan dengan keterlibatan "oknum” yang mengaku dan ditengarai bagian dari komunitas Muslim. Pengulangan isu tentang moderasi Islam ini terus diulang-ulang dalam pemberitaan Koran Republika, paling tidak yang ditemukan itu sepanjang periode tahun 2017-2019.

Koran Republika kalau dibandingkan dengan media cetak lainnya sudah berperan dan berfungsi secara aktif untuk mempromosikan narasi moderasi Islam kepada khalayak melalui media cetak atau surat kabar, sehingga menjadi opini publik yang layak dan menarik untuk diperbincangkan di tengah-tengah masyarakat. Dalam hal ini, Koran Republika sudah berperan sebagai penyalur dan pembawa pesan atau informasi tentang moderasi Islam Indonesia kepada khalayak. Koran Republika juga sudah membantu menciptakan suasana lebih sejuk dan memfasilitasi berkembangnya gagasan yang kreatif dan konstruktif berkenaan dengan wacana moderasi Islam Indonesia. Juga Koran Republika sudah berusaha mengembangkan pendapat umum berdasarkan infomasi yang tepat, akurat, dan benar mengenai sosialisasi dan publikasi moderasi Islam Indonesia. Sehingga pada gilirannya terbentuk suatu pendapat umum mengenai pentingnya penguatan narasi moderasi Islam Indonesia di tengah-tengah masyarakat.

\section{PENUTUP}

Narasi moderasi Islam Indonesia dimaksudkan untuk pengarusutamaan dalam upaya mereduksi tindakan kekerasan bernuansa agama yang kerapkali terjadi di Indonesia. Sehingga perlu menguatkan nilai keagamaan dan nilai kebangsaan secara simultan (bersamaan) dalam masyarakat Indonesia yang plural dan multikultural di bawah landasan Pancasila, UUD 1945, Negara Kesatuan Republik Indonesia (NKRI) dan Bhineka Tunggal Ika. Di sinilah pentingnya mengkaji narasi moderasi Islam Indonesia yang dipublikasikan melalui media cetak Koran Republika sepanjang periode 2017-2019.

Pemberitaan Koran Republika memiliki peran yang nyata dalam upaya menyebarkan informasi dan membentuk opini di tengah masyarakat mengenai penguatan dan pengarusutamaan moderasi Islam Indonesia. Konstruksi berita mengenai Dakwah moderasi Islam Indonesia tersebut sesuai dengan visi dan misi Koran Republika sebagai media penyebar aspirasi komunitas Muslim yang moderat dan kosmopolitan dalam upaya menjaga persatuan dan kesatuan bangsa Indonesia. Maka sepanjang periode 2017-2019 terdapat 21 artikel berita yang dimuat Koran Republika yang semuanya menyajikan tentang narasi moderasi Islam Indonesia. Ini sejalan dengan teori representasi media, bahwa Koran Republika dapat dipandang sebagai media representasi Muslim yang memiliki 
komitmen dan konsisten mempublikasikan syiar dakwah Islam dan aspirasi umat Islam Indonesia yang memiliki kekhasan moderat.

Penelitian ini merupakan penelitian pendahuluan untuk membuka jalan terhadap penelitian-penelitian selanjutnya tentang kajian agama dan media. Maka dapat dilanjutkan dengan penelitian-penelitian yang serupa tetapi memiliki distingsi yang berbeda, misalnya melalui media digital ataupun media sosial (medsos). Sehingga dapat menambah khazanah pengetahuan dan wawasan mengenai kajian agama dan media.

\section{DAFTAR PUSTAKA}

Al-Rasyid, H. H. (2014). Dakwah Islam Di Era Globalisasi: Revitalisasi Prinsip Moderasi Islam, Jurnal "Al-Qalam" Vol. 20 Edisis Khusus, 1-12.

Amalia, A., \& Haris, A. (2019). Wacana Islamophobia Di Media Massa, Medium: Jurnal Ilmiah Fakultas Ilmu Komunikeasi Universitas Islam Riau, 7(1), 71-81.

Amin, M. Y. (2020). Komunikasi dan Demokrasi, Pilar Utama Membangun Moderasi Islam, At Tabsyir: Jurnal Komunikasi Penyiaran Islam IAIN Kudus, 7(1), 81-107.

Ardianto, E., dkk. (2007). Komunikasi Massa Suatu Pengantar. Bandung: Simbiosa.

Aziz, M. A. (2017). Media Massa Islam Dalam Tatangan Global (Analisis Dakwah dan Cyber Media di Indonesia), Islamic Comunication journal, 2(2), 200-218.

Budiasa, M. (2017). Mediatisasi Aksi Massa Islam 2 Desember 2016, Profetik Jurnal Komunikasi, 10(1), 35-49.

Effendy, O. U. (1993). Ilmu, Teori \& Filsafat Komunikasi. Bandung: Aditya Bakti. Eriyanto. (2018). Analisis Wacana Pengantar Analisis Teks Media. Yogyakarta: Lkis.

Faiqah, N., \& Pransiska, T. (2018). Radikalisme Islam VS Moderasi Islam: Upaya Membangun Wajah Islam Indonesia yang Damai, Al-Fikra: Jurnal Ilmiah Keislaman, 17(1), 33-60.

Hanafi, M. M. (2018). Damai Bersama Al-Qur'an. Jakarta: Lajnah Pentashihan Mushaf Al-Qur'an Badan Litbang dan Diklat Kementerian Agama RI.

Ilaihi, W. (2010). Komunikasi Dakwah. Bandung: Rosdakarya.

Kantor Utusan Khusus Presiden Untuk Dialogi dan Kerja Sama Antar Agama dan Peradaban. (2018). Wasatiyyat Islam: Konsepsi dan Implementasi. Jakarta: KTT Ulama dan Cendikiawan Muslim Dunia.

Kasman, S. (2010). Pers dan Pencitraan Umat Islam di Indonesia. Jakarta: Badan Litbang dan Diklat Kementerian Agama.

Kementerian Agama. (2014). Al-Qur'an dan Terjemahnya. Tangerang: Panca Cemerlang.

Kementerian Agama. (2019). Moderasi Beragama. Jakarta: Badan Litbang dan Diklat Kementerian Agama. 
Dudung Abdul Rohman

Mamdud, R. (2019). Dakwah Islam di Media Massa, Al-I'lam; Jurnal Komunikasi dan Penyiaran Islam, 3(1), 47-54.

Mas'ud, A. (2011). Moderasi Gerakan Islam, Jurnal Dialog, 71:1.

Mubakkirah, F. (2018). Moderasi Islam: Dari Konsep Menuju Identitas, Bilancia, 12(2), 241-261.

Muhtadi, A. S. (1999). Jurnalistik Pendekatan Teori dan Praktek, Jakarta: Logos.

Pradipta, A. L., Nur Hidayah, N. W., Haya, A. N. A., Ervania, C., \& Kristanto, D. (2018). Analisis Bingkai Pemberitaan Aksi Bela Islam 2 Desember 2016 (Aksi 212) di Media Massa BBC (Indonesia) \& Republika, Informasi: Kajian Ilmu Komunikasi, 48(1), 109-124.

Qardhawi, Y.(1996). Karakteristik Islam: Kajian Analitik. Terjemahan oleh Rofi Munawwar dan Tajudin. Surabaya: Risalah Gusti.

Qudratullah. (2017). Jurnalistik Islami di Media Massa, Jurnal Dakwah Tabligh, 18(2), 107-127.

Ramdhan, T. W. (2018). Dimensi Moderasi Islam, Al-Insyirob, 2(1), $29-48$.

Riyanto, W. F. (2013). Islam dan Media Massa: Pertautan Triadik antara Tuhan, Manusia dan Budaya, Jurnal Islamic Review, 2(2), 285-310.

Sri Rizki, J. W. (2018). Peran Media Massa dalam Reaktulisasi Kemajuan Peradaban Islam (Analisis Wacana Terhadap Rubrik Mimbar Jumat di Surat Kabar Harian), TAZKIR: Jurnal Penelitian Ilmu-ilmu Sosial dan Keislaman, 4(1), 1-15.

Taher, T. (2007). Berislam Secara Moderat. Jakarta: Grafindo.

Vivian, J. (2008). Teori Komunikasi Massa. Terjemahan oleh Tri Wibowo. Jakarta: Kencana.

Wanodya, A. G. (2018). Penyetiran Opini Publik di Media Massa: Telaah Teori Konspirasi atas Pelemahan Islam, Fikrah: Jurnal Ilmu Aqidah dan Studi Keagamaan, 6(1), 117-140. 